\title{
Karakteristik Kuat Geser Tanah Lempung Ekspansif di Sekitar Kolom SiCC
}

\author{
Mei Liya Faridatun Kharoza ${ }^{\mathrm{a}}$, Agus Setyo Muntohar ${ }^{\mathrm{b} *}$, Willis Diana $^{\mathrm{b}}$, Edi Hartono ${ }^{\mathrm{b}}$ \\ ${ }^{a}$ Engineer Department Manufacturing Excellent, PT. Hwa Seung Indonesia, Jepara, Jawa Tengah. \\ ${ }^{b}$ Program Studi Teknik Sipil, Fakultas Teknik, Universitas Muhammadiyah Yogyakarta
}

Riwayat Artikel

Diserahkan

1 Desember 2020

Direvisi

4 Januari 2021

Diterima

1 Februari 2021

*Penulis korespondensi muntohar@umy.ac.id

\begin{abstract}
Abstrak
Tanah lempung ekspansif memiliki kembang dan susut yang sangat besar, dimana pengembangan terjadi pada musim hujan dan menyusut pada musim kemarau. Hal ini menyebabkan rendahnya daya dukung tanah dan berakibat pula pada kekuatan struktur yang akan dibangun di atasnya. Penelitian kuat dukung tanah dengan perkuatan kolom SiCC sudah dilakukan sebelumnya, namun karakteristik kuat geser tanah di sekitar kolom SiCC belum dikaji. Sehingga, pada penelitian ini dilakukan penelitian lanjutan untuk mengkaji kuat geser dan perilaku tanah disekitar kolom SiCC. Pada penelitian ini, kuat geser tanah disekitar kolom SiCC diuji dengan triaksial kondisi UU dan CU. Tekanan sel yang diberikan pada kondisi UU sebesar 49,05 kPa, 61,31 kPa, dan 73,58 kPa. Sedangkan tekanan sel yang diberikan pada kondisi CU sebesar 98,1 kPa, 196, $2 \mathrm{kPa}$, dan 294, 3 $\mathrm{kPa}$. Tegangan aksial diberikan melalui tegangan deviator dengan kecepatan pembebanan 1,674 $\mathrm{mm} /$ menit pada kondisi UU dan $0,05 \mathrm{~mm} /$ menit pada kondisi CU hingga benda uji mencapai keruntuhan. Hasil penelitian menunjukkan bahwa kekuatan dan kekakuan tanah lebih tinggi terjadi di dekat kolom SiCC dan menurun dengan jarak dari pusat kolom SiCC.

Kata-kata kunci: lempung ekspansif, kolom SICC, triaksial, UU, CU

(c) 2021 Penerbit UMY. All rights reserved
\end{abstract}

\section{PENDAHULUAN}

Banyak konstruksi sipil seperti jalan raya, bangunan gedung, bendungan, dan sebagainya, seringkali dihadapkan pada permasalahan rendahnya kuat dukung dan buruknya sifat - sifat tanah lainnya (Muntohar, 2014). Tanah lempung ekspansif memiliki kembang dan susut yang sangat besar, dimana pengembangan terjadi pada musim hujan dan menyusut pada musim kemarau. Hal ini menyebabkan rendahnya daya dukung tanah dan berakibat pula pada kekuatan struktur yang akan dibangun di atasnya. Oleh karena itu, pekerjaan perbaikan tanah terlebih dahulu dilakukan sebelum tanah digunakan untuk menopang struktur di atasnya. Salah satu metode perbaikan tanah lempung adalah dengan cara teknik kolom, yaitu dengan menambahkan kolom ke dalam tanah lempung ekspansif, yang bertujuan agar dapat menambah daya dukung tanah.

Beberapa penelitian tentang stabilisasi tanah dengan teknik kolom kapur baik dengan campuran semen atau abu terbang telah banyak dilakukan oleh para peneliti (Hewayde dkk., 2005; Tonoz dkk., 2003; Budi, 2003;
Muntohar, 2010). Muntohar dan Liao ( 2006) melakukan uji laboratorium untuk mengkaji kapur kolom sebagai kolom tunggal yang berdiameter $5 \mathrm{~cm}$ dan panjang $20 \mathrm{~cm}$ dengan hasil kapur kolom dalam tanah dapat meningkatkan kekuatan tanah disekitarnya, di kedua arah yaitu arah radial sebesar 3D dan pada arah vertikal sebesar 8D. Muntohar dkk. (2014) menggunakan bahan SiCC sebagai pengisi kolom untuk mendukung sistem perkerasan jalan. Penelitian kuat dukung tanah dengan perkuatan kolom SiCC sudah dilakukan oleh Muntohar dkk. (2020) dengan bermacam bentuk dan panjang kolom. Penelitian tersebut mengkaji deformasi dan pembebanan pada tanah lempung ekspansif yang diberi kolom T-Shape dengan panjang $70 \mathrm{~cm}$ dan $50 \mathrm{~cm}$ yang diameter 5,08 cm. Sedangkan karakteristk kuat geser tanah di sekitar kolom SiCC belum dikaji. Sehingga, pada penelitian ini dilakukan penelitian lanjutan untuk mengkaji kuat geser dan perilaku tanah disekitar kolom SiCC. Jenis pengujian yang dilakukan adalah uji triaksial kondisi unconsolidated-undrained (UU) dan consolidated-undrained (CU). Tujuan dari penelitian ini 
adalah untuk mengkaji kuat geser dan perilaku tanah disekitar kolom SiCC dengan pengujian triaksial kondisi UU dan CU pada tanah lempung ekspansif.

\section{METODE PENELITIAN}

\subsection{Desain Penelitian}

Kondisi tanah yang diuji seperti pada Gambar 1. Pada penelitian ini, kuat geser tanah disekitar kolom SiCC diuji dengan triaksial kondisi UU dan CU. Tekanan sel yang diberikan pada kondisi UU sebesar 49,05 kPa, 61,31 $\mathrm{kPa}$, dan $73,58 \mathrm{kPa}$. Sedangkan tekanan sel yang diberikan pada kondisi CU sebesar 98,1 kPa, 196, 2 kPa, dan 294, 3 $\mathrm{kPa}$. Tegangan aksial diberikan melalui tegangan deviator dengan kecepatan pembebanan $1,674 \mathrm{~mm} /$ menit pada kondisi UU dan $0,05 \mathrm{~mm} /$ menit pada kondisi CU hingga benda uji mencapai keruntuhan. Pada penelitian ini, sampel yang digunakan merupakan tanah yang sudah distabilisasi menggunakan kolom $\mathrm{SiCC}$ yang memiliki panjang $70 \mathrm{~cm}$ dengan diameter atas dan bawahnya sebesar 2 inch atau $5,08 \mathrm{~cm}$.

\subsection{Tanah yang digunakan}

Pada penelitian ini menggunakan tanah lempung ekspansif yang berasal dari daerah Ngawi, Jawa Timur. Pengujian dilakukan di Laboratorium Geoteknik Jurusan Teknik Sipil, Universitas Muhammadiyah Yogyakarta. Sifat - sifat fisik dan indeks disajikan pada Tabel 1.

\subsection{Alat yang digunakan.}

Untuk uji triaksial kondisi unconsolidated-undrained (UU), digunakan alat uji triaksial dengan dinding transparan dan perlengkapannya seperti pada Gambar 2. Dalam penelitian ini digunakan triaxial digital untuk uji triaksial dalam kondisi consolidated-undrained (CU) yang hasilnya langsung terbaca di komputer. Satu set triaxial digital terdiri atas unit panel dan unit load frame (Gambar 3). Triaxial digital dapat digunakan untuk ketiga jenis pengujian triaxial, yaitu UU, CU, dan CD.

\subsection{Pembuatan Benda Uji dan Prosedur Pengujian}

Tanah lempung ekspansif terlebih dahulu di uji sifat - sifat tanah aslinya berupa kadar air, berat jenis, batas batas Atterberg, dan distribusi ukuran butir tanah. Setelah pengujian awal, tanah yang berada di drum diambil

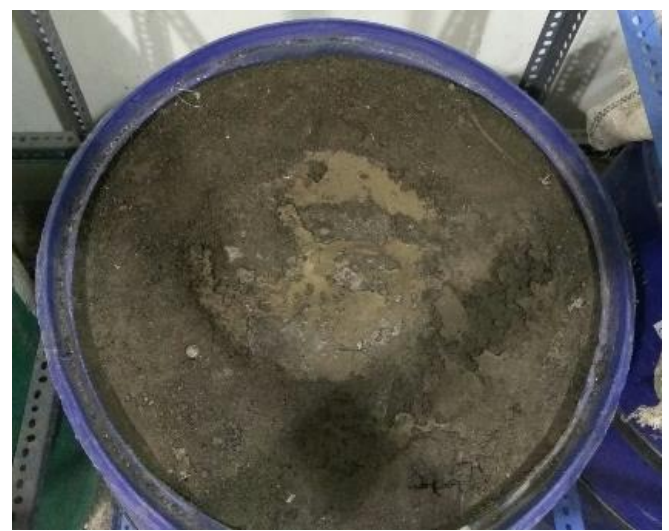

Gambar 1 Kondisi tanah lempung ekspansif dalam drum percobaan.
Tabel 1 Sifat-sifat indek tanah

\begin{tabular}{ll}
\hline Parameter & Nilai \\
\hline Kadar air, w (\%) & 49,11 \\
Berat jenis, $\mathrm{G}_{\mathrm{s}}$ & 2,63 \\
Batas - batas Atterberg: & \\
Batas cair, LL (\%) & 73 \\
Batas plastis, PL (\%) & 39,8 \\
Batas susut, SL (\%) & 17,7 \\
Indeks plastisitas, PI (\%) & 33,2 \\
Klasifikasi USCS & $\mathrm{MH}$ \\
\hline
\end{tabular}

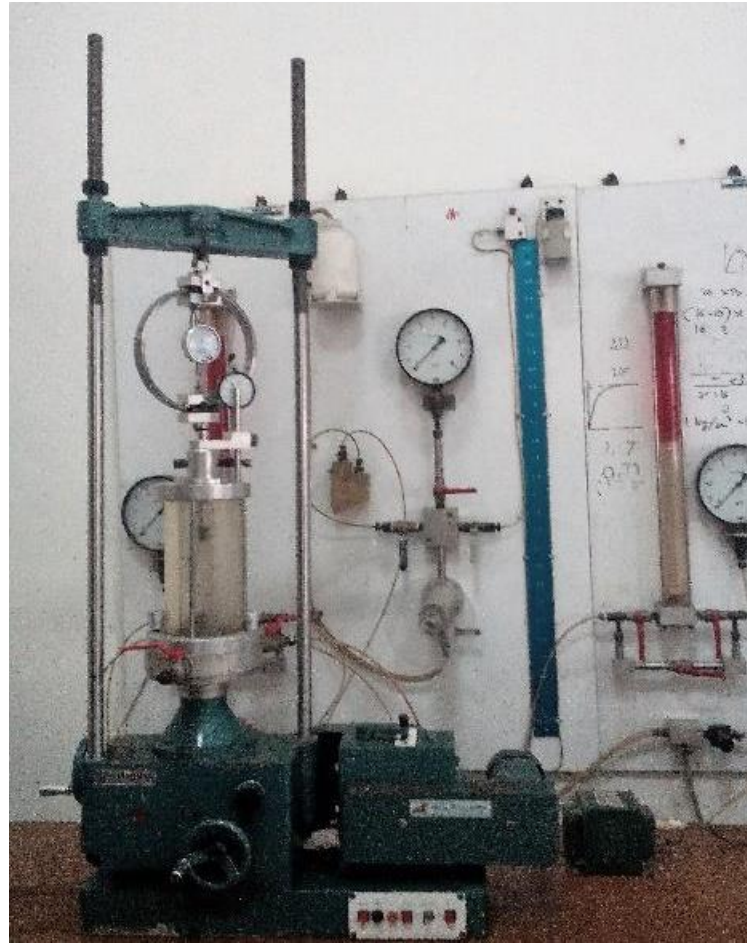

Gambar 2 Alat Uji Triaksial dengan Dinding Transparan dan Perlengkapan

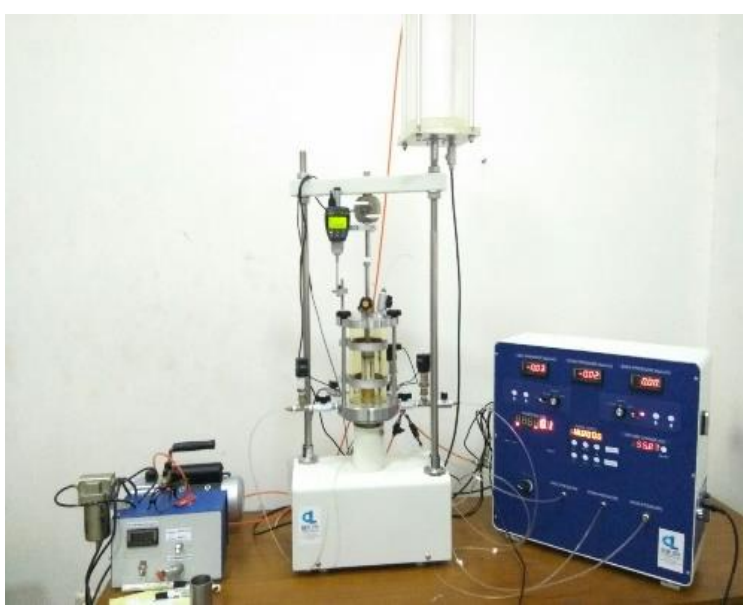

Gambar 3 Triaxial Digital

menggunakan pipa secara vertikal sesuai dengan rencana pengujian seperti Gambar 4. Tanah yang sudah diambil, kemudian dicetak menggunakan silinder cetakan berukuran $38 \mathrm{~mm}$ x $76 \mathrm{~mm}$, lalu dikeluarkan dari cetakan benda uji menggunakan extruder. Kemudian benda uji diukur dimensinya dan ditimbang beratnya. 


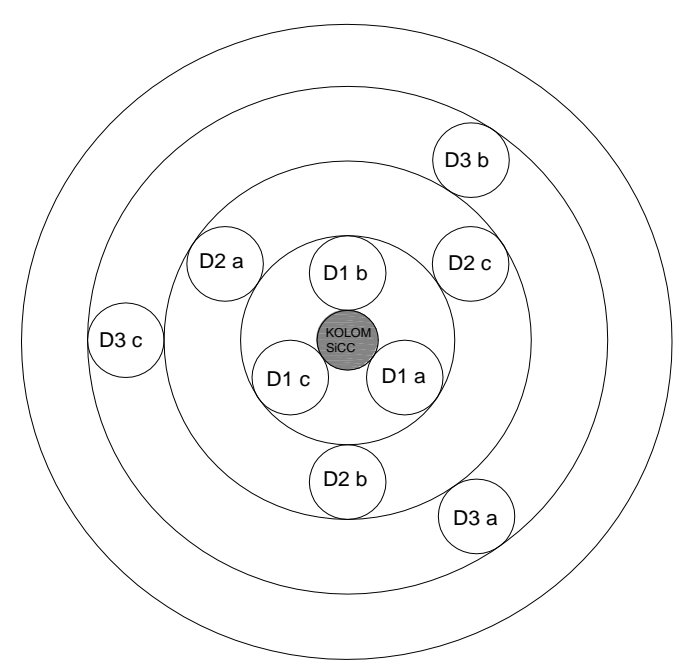

(a)

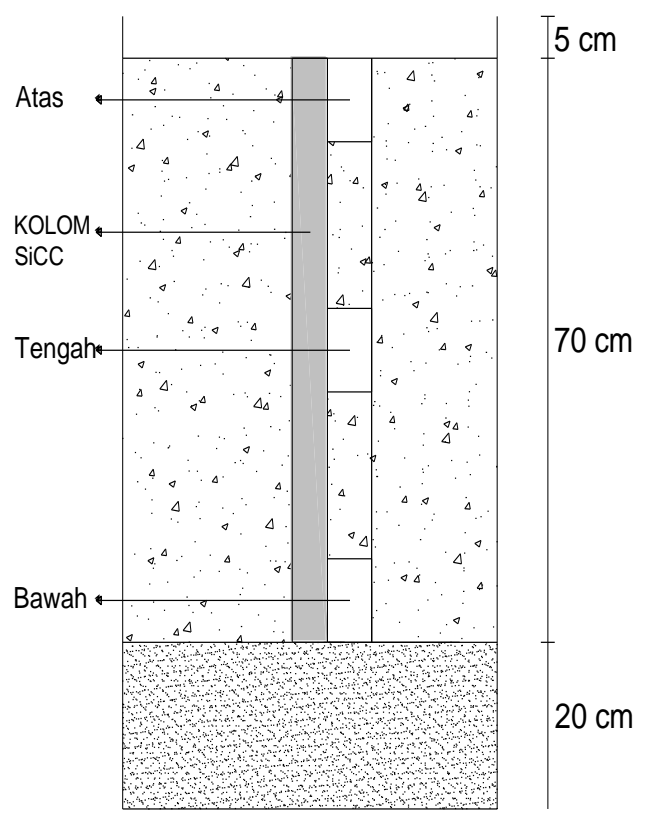

(b)

Gambar 4 Sketsa pengambilan benda uji (a) titik-titik pengambilan contoh tanah, (b) potongan melintang

\section{HASIL DAN PEMBAHASAN}

\subsection{Uji Triaksial}

Hasil pengujian triaksial UU berupa hubungan tegangan deviatorik dan regangan aksial diberikan pada Gambar 5. Pada jarak 1D tegangan deviatorik tertinggi sebesar 71,94 kPa, 83,49 kPa, 115,14 kPa, sedangkan pada diameter D2 tegangan deviatorik tertinggi sebesar 75,69 $\mathrm{kPa}, 94,88 \mathrm{kPa}, 98,33 \mathrm{kPa}$, dan untuk diameter D3 tegangan deviatorik tertinggi sebesar $71,49 \mathrm{kPa}, 75,17$ $\mathrm{kPa}, 102,25 \mathrm{kPa}$ untuk masing - masing tekanan sel 49,05 $\mathrm{kPa}, 61,31 \mathrm{kPa}$, dan $73,58 \mathrm{kPa}$.

Pada penelitian ini digunakan 2 alat uji triaksial yang berbeda untuk masing - masing kondisi unconsolidatedundrained (UU) dan consolidated-undrained (CU). Prosedur pengujian triaksial mengikuti SNI 4813:2015 untuk kondisi UU dan SNI 2455:2015 untuk kondisi CU. Tegangan deviatorik dan tegangan geser dapat dinyatakan dalam hubungan lintasan keruntuhan sebagai kurva $\mathrm{p}-\mathrm{q}$ seperti pada Gambar 6. Kuat geser tanah diukur dengan dua parameter, yaitu nilai sudut gesek internal $(\varphi)$, dan nilai kohesi (c). Paramater lain yang dapat diperoleh dari uji triaksil adalah modulus deformasi $\left(\mathrm{E}_{50}\right)$.

Hasil dari tegangan deviatorik maksimal pada D1 ke D2 terjadi peningkatan pada tekanan sel 49,05 $\mathrm{kPa}$ dan $61,31 \mathrm{kPa}$ masing - masing sebesar $6,5 \%$ dan $8,1 \%$, sedangkan pada tekanan sel 73,58 $\mathrm{kPa}$ menurun sebesar $12,7 \%$. Hasil dari tegangan deviatorik maksimal pada D2

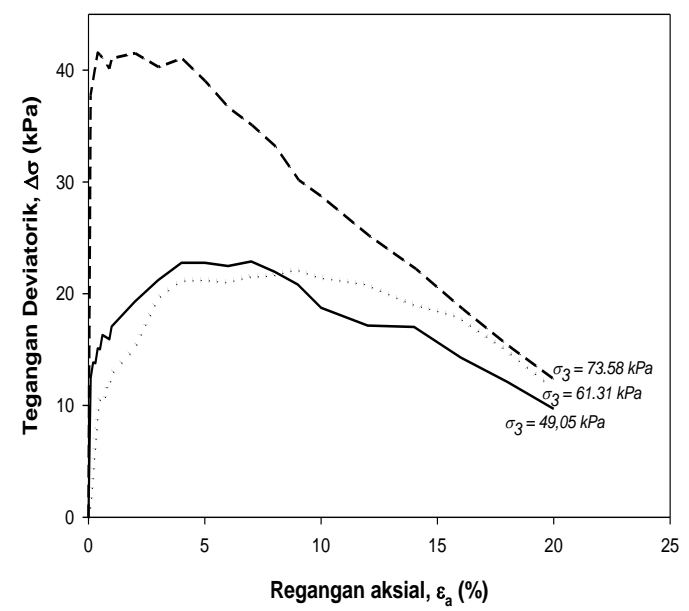

(a)

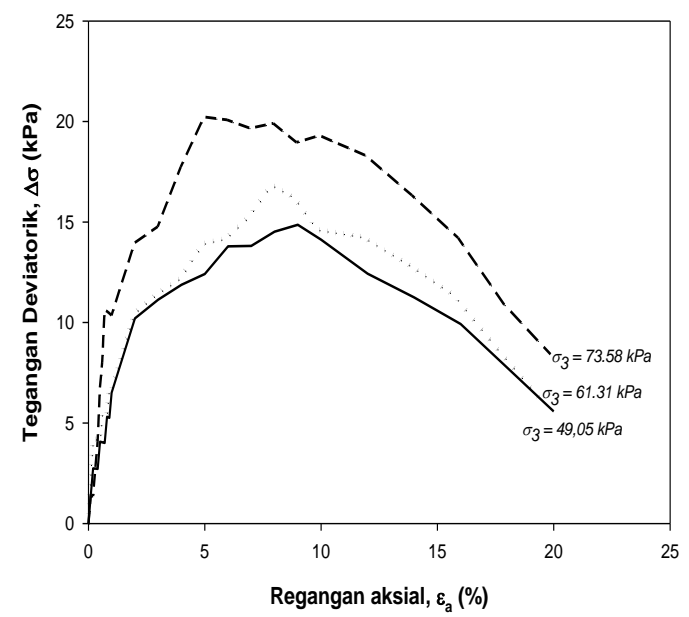

(b)

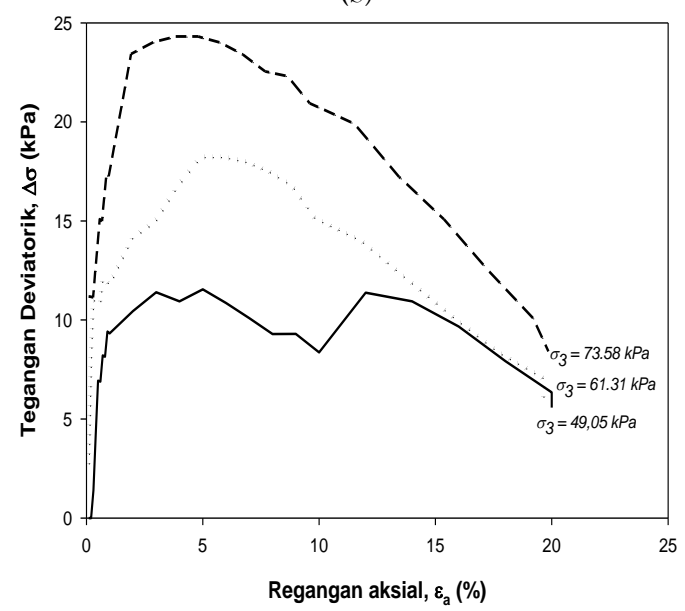

(c)

Gambar 5 Kurva hubungan teganan deviatorik dan regangan aksial (a) D1, (b) D2, (c) D3 


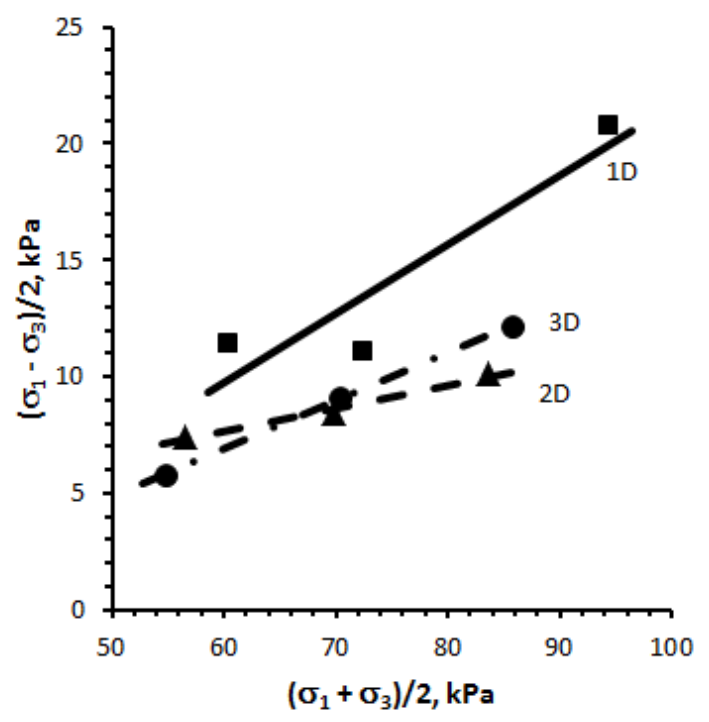

Gambar 6 Selubung keruntuhan pada uji triaksial UU

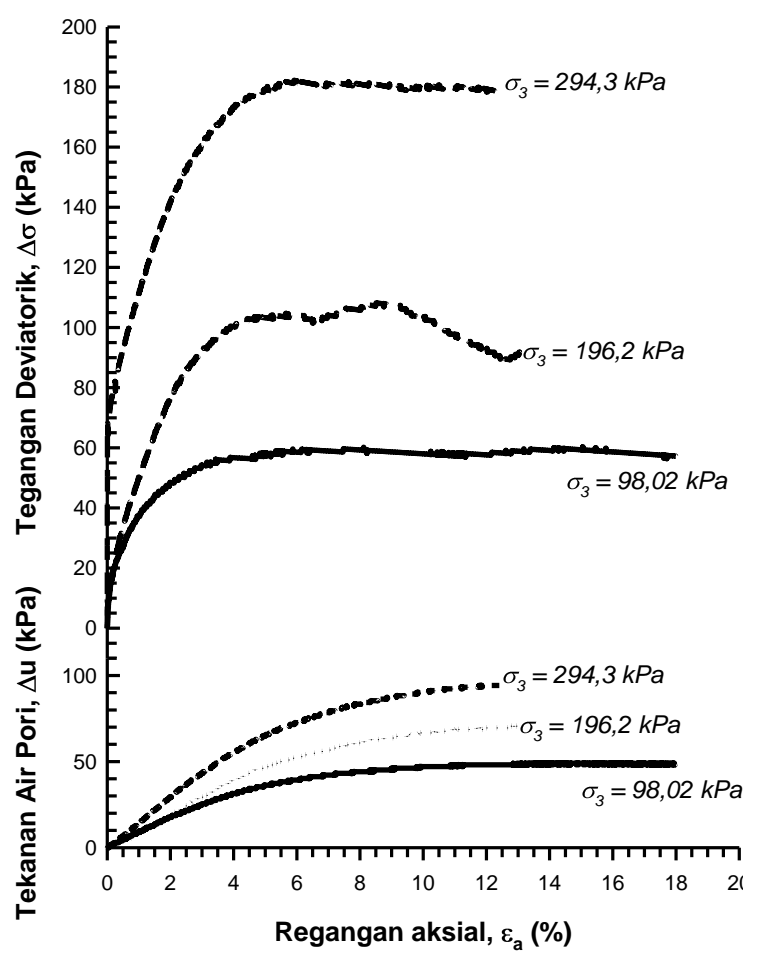

Gambar 7 Kurva hubungan teganan deviatorik dan regangan untuk benda uji tanah dengan kolom

ke D3 terjadi penurunan pada tekanan sel 49,05 $\mathrm{kPa}$ dan $61,31 \mathrm{kPa}$ masing - masing sebesar 10,9\% dan 6,9\%, sedangkan pada tekanan sel 73,58 kPa meningkat sebesar $4,3 \%$.

Hasil pengujian triaksial CU berupa hubungan tegangan deviatorik dan regangan aksial diberikan pada Gambar 7. Hasil dari tegangan deviatorik tanpa kolom sebesa $152,49 \mathrm{kPa}, 316,99 \mathrm{kPa}, 429,52 \mathrm{kPa}$ dan hasil tegangan deviatorik menggunakan kolom sebesar 158,27 $\mathrm{kPa}, 304,35 \mathrm{kPa}, 476,50 \mathrm{kPa}$ untuk masing - masing tekanan sel 98,1 kPa, 196,2 kPa, dan 294,3 kPa. Tekanan air pori yang terjadi pada tanah tanpa kolom berturut turut sebesar $51,99 \mathrm{kPa}, 74,56 \mathrm{kPa}, 83,39 \mathrm{kPa}$ dan untuk tanah menggunakan kolom sebesar 49,05 kPa, 62,78 kPa, dan 71,61 kPa. Selubung keruntuhan untuk masing-

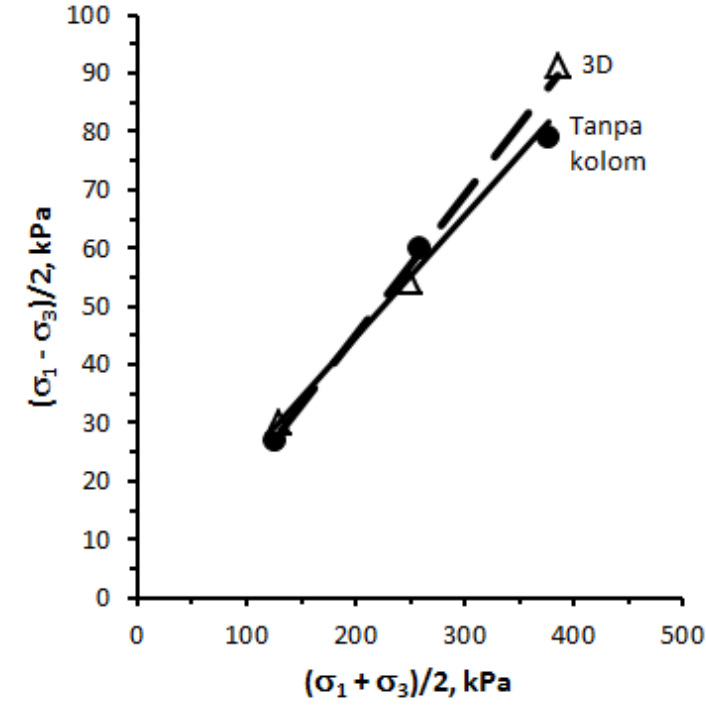

Gambar 8 Selubung keruntuhan teganan total hasil uji triaksial CU

Tabel 2 Parameter kuat geser tanah dari uji triaksial CU

\begin{tabular}{lll}
\hline Parameter & Tanpa Kolom & Dengan Kolom \\
\hline $\mathrm{c}(\mathrm{kPa})$ & 8,8 & 0 \\
$\phi\left({ }^{\circ}\right)$ & 9,98 & 13,75 \\
$\mathrm{c}^{\prime}(\mathrm{kPa})$ & 15,64 & 8,27 \\
$\phi^{\prime}\left({ }^{(}\right)$ & 11,45 & 15,12 \\
$\mathrm{E}_{50}(\mathrm{MPa})$ & $3,03-13,2$ & $4,81-20,24$ \\
\hline
\end{tabular}

masing benda uji seperti pada Gambar 8. Berdasarkan selubung keruntuhan ini dapat diperoleh parameter kuat geser tanah seperti disajikan dalam Tabel 2.

\subsection{Pembahasan \\ Parameter kuat geser tehadap jarak dari kolom}

Kuat geser tanah diukur dengan 2 parameter tanah, yaitu nilai sudut gesek internal $(\varphi)$, dan nilai kohesi (cNilai $\varphi$ adalah gesekan antara butiran tanah sedangkan nilai c adalah gaya tarik - menarik antar partikel tanah (Ermina, et al, 2012). ). Gambar 9 menyajikan hubungan natar parameter kuat geser tanah dan jarak dari pusat kolom SiCC. Hasil dari uji triaksial kondisi UU dan CU menjelaskan jika titik pengambilan tanah semakin jauh dari pusat kolom, maka nilai $\varphi$ lebih besar sedangkan nilai c semakin kecil. Maka semakin jauh dari pusat kolom, tanah tersebut memiliki gaya gesek yang besar dengan kelekatan antar partikel yang kecil, sehingga tanah lebih tidak stabil.

Hasil pengujian triaksial kondisi UU dan CU berupa hubungan tegangan deviatorik dan regangan aksial, secara umum tegangan deviatorik meningkat seiring dengan peningkatan tekanan sel yang diberikan. Tetapi, tegangan deviatorik lebih tinggi terjadi dekat kolom dan menurun dengan jarak dari pusat kolom. Menurut Muntohar \& Liao (2006) kekuatan yang lebih tinggi terjadi di dekat kolom, dan menurun dengan jarak dari pusat kolom.

\section{Modulus deformasi terhadap jarak dari kolom}

Paramater lain yang dapat diperoleh dari uji triaksil adalah modulus deformasi $\left(E_{50}\right)$. Nilai $E_{50}$ didapat dari perbandingan tegangan deviatorik $50 \%$ dengan regangan pada saat tegangan deviatorik 50\%. Gambar 10 
Kharoza, Muntohar, Diana \& Hartono / Buletin Teknik Sipil 1:1 (2021) 7-11

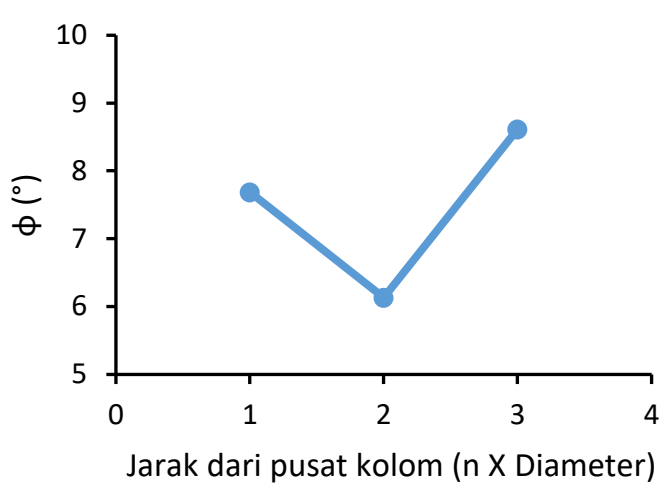

(a)

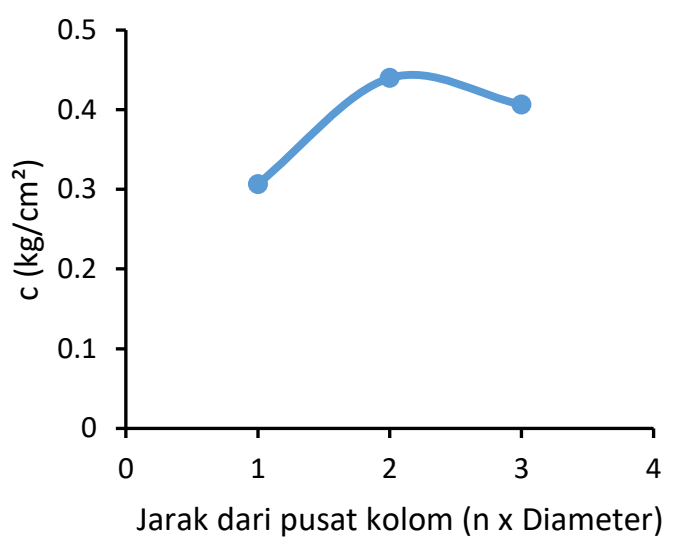

(b)

Gambar 9 Kurva hasil parameter tanah (a) Nilai sudut gesek tanah, (b) Nilai kohesi

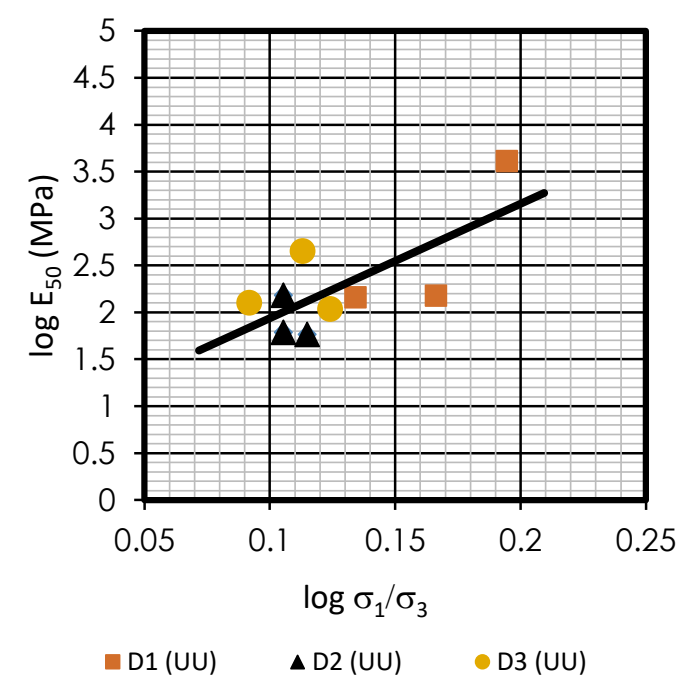

Gambar 10 Hubungan tegangan $\mathrm{E}_{50}$ dan $\sigma_{1} / \sigma_{3}$ untuk berbagai jarak dari pusat kolom

menyajikan hubungan antara nilai $E_{50}$ terhadap perubahan tegangan aksial dan tegangan sel. Berdasarkan nilai modulus deformasi yang didapatkan untuk uji triaksial UU pada setiap diameter, terjadi penurunan nilai modulus deformasi dari jarak 1D ke 3D, sehingga tanah tersebut semakin jauh dari pusat kolom maka tanah tersebut semakin elastis. Untuk uji triaksial CU, pengaruh nilai modulus deformasi tidak dapat di analisis karena kurangnya data yang diambil. Kemiringan garis pada kurva p - q menunjukkan sifat nonmonotonik untuk uji triaksial UU, sedangkan untuk uji triaksial CU kemiringan garis menunjukkan sifat monotonik.

\section{KESIMPULAN}

Berdasarkan hasil penelitian dan analisa dapat disimpulkan bahwa:

1. Nilai tegangan deviatorik meningkat seiring dengan peningkatan tekanan sel yang diberikan

2. Kekuatan tanah lebih tinggi terjadi di dekat kolom SiCC dan menurun dengan jarak dari pusat kolom SiCC.

3. Kekakuan tanah lebih tinggi terjadi di dekat kolom SiCC dan menurun dengan jarak dari pusat kolom SiCC.

\section{Ucapan Terima Kasih}

Terima kasih kepada Direktorat Riset dan Pengabdian kepada Masyarakat, Kementrian Riset, Teknologi, dan Pendidikan Tinggi atas pendanaan penelitian melalui Riset Pengembangan Ilmu Pengetahuan Dan Teknologi (IPTEK) tahun 2016.

\section{Daftar Pustaka}

Budi, G.S., 2003, Penyebaran kekuatan dari kolom yang terbuat dari limbah karbit dan kapur. Jurnal Dimensi Teknik Sipil 5(2). 99-102.

Hewayde, E, El Naggar, H., Khorshid, N. 2005. Reinforced lime columns: a new technique for heave control. Ground Improvement 9(2): $79-87$

Ermina, R., Nugroho, S. A., Putra, A. I.,2012. Korelasi Parameter Kuat Geser Tanah Hasil Pengujian Triaksial dan Unconfined Compression Strength (UCS), Jurnal Sains dan Teknologi 11(1), 1-10

Muntohar, A.S., Liao, H.J., 2006, Strength distribution of the soil surrounding lime-column, In Chan, D., and Law, K.T. (Eds.) : Proceeding 4th International Conference on Soft Soil Engineering, 2-6 October 2006, Vancouver, Canada, 315-319

Muntohar, A. S., 2010, A laboratory test on the strength and load-settlement characteristic of improved soft soil using lime-column, Dinamika Teknik Sipil 10(3), 202 207

Muntohar, A.S., 2014. Prinsip - Prinsip Perbaikan Tanah. Yogyakarta: LP3M UMY.

Muntohar, A.S., Rosyidi, S.A.P., Diana, W., Iswanto, 2014, Perilaku Beban-Deformasi Pelat Fleksibel Didukung dengan Kolom-Kolom Eco-SiCC di Tanah Ekspansif, Konferensi Nasional Teknik Sipil 8 (KoNTekS 8), Institut Teknologi Nasional, Bandung, Indonesia, 16-18 Oktober 2014, pp. STR95-STR10

Muntohar, A.S., Diana, W., Tafalas, M.Y., Bimantara, N.R., 2020. The Behavior of the Flexible Plate-Supported with SiCC-Mortar Column on Expansive Soil. International Journal of Technology 11(1), 123-132

Tonoz, M.C., Gokceoglu, C., dan Ulusay, R., 2003, A laboratoryscale experimental investigation on the performance of lime in expansive Ankara (Turkey) clay, Bulletin Engineering Geology $\mathcal{E}$ Environmental 62, 91-106 